\title{
Why Rural Principals Leave
}

\author{
Cindy Hansen
}

The purpose of this qualitative study was to explore the factors that influenced a principal's decision to leave his or her rural school. Six principals who left their rural Minnesota schools within the previous year were interviewed to determine the perceived factors that led to their departure decisions. Factors were grouped into personal, institutional, and environmental categories. Interviews were transcribed, coded, and analyzed for themes through a rigorous process that included inter-rater reliability checks with an independent researcher and repeated member checks with respondents. Themes were codes that occurred for more than half of respondents and included Family Needs, Career Aspirations, Community Expectations, Workload, Lack of Professional Support, Superintendent and School Board (General Decisions or Relationship), and Superintendent and School Board (Principal Salary and Contract Negotiations). Limitations and suggestions for future research are discussed.

\section{Introduction}

In an era of increased school accountability, principal turnover is gaining momentum as a reporting endeavor. News organizations from Massachusetts (Tuoti \& Sanna, 2016) to Texas (Hacker, 2015) to Alaska (Kraegel, 2016) have noted high turnover rates of principals. Other organizations, like The Chicago Public Education Fund (2015), have published call-to-action reports that describe the urgency of their "fight to keep top principals" (n.p.). Some states have even started reporting principal turnover rates on their annual school accountability reports (Illinois State Board of Education, 2016).

Reporters have cause for concern. More than one in five principals leave their positions each year (National Center for Education Statistics, 2013), and several studies (Branch, Hanushek, \& Rivkin, 2013; Brockmeier, Starr, Green, Pate, \& Leech, 2013; Mascall \& Leithwood, 2010; Miller, 2013) have linked frequent principal turnover to negative outcomes, especially reduced student achievement. Miller (2013) echoed the findings of many researchers when she wrote, "Student test scores are substantially lower at schools with new principals" (p. 64).

\section{The Rural Context}

The problem of principal turnover is especially critical for rural schools. A variety of studies from the United States and beyond (DeAngelis \& White, 2011; Ewington et al., 2008; Halsey \& Drummond, 2014; Morford, 2002; Partlow \& Ridenour, 2008; Starr \& White, 2008) demonstrate higher principal turnover rates in rural districts than in other districts. Additional research indicates that rural schools must overcome significant challenges to attract and retain high-quality administrators (Pijanowski, Hewitt, \& Brady, 2009; Preston, Jakubiec, \& Kooymans, 2013), including smaller applicant pools, geographic isolation, community expectations and pressure, and limited salary and budget.

\section{Relevant Literature}

Researchers have described the topic of principal turnover as being in its "infancy" (Farley-Ripple, Solano, \& McDuffie, 2012; Loeb, Kalogrides, \& Horng, 2010). Studies in the United States on this topic (Baker, Punswick, \& Belt, 2010; Battle, 2010; Branch et al., 2013; Gates et al., 2006; Papa, 2007; Sun \& Ni, 2016; Tekleselassie \& Villarreal III, 2011) have been overwhelmingly quantitative and limited to the pre-defined variables in state or national education databases. Thus, existing literature tends to correlate principal turnover to variables such as gender, age, experience, or school poverty rate. Interestingly, these analyses sometimes present conflicting evidence. For instance, Gates et al. (2006) found that female principals were slightly more likely to leave, but other researchers (Battle, 2010; Sun \& Ni, 2016; Tekleselassie \& Villarreal III, 2011) found that female principals were more likely to stay.

Although demographic variables are important, the focus of this literature review is the principal's perception of factors that influence his or her departure decision. Even if those perceived factors do not align with numerical databases or observed reality, they are imperative to understanding the motivations behind career decisions, because people's perceptions influence their behavior. The factors explored in this study can be divided into at least three categories: personal factors, institutional factors, and environmental factors. 


\section{Personal Factors}

Personal factors are those within the realm of control or influence of the principal, and they include family needs and career aspirations. Existing research presents the factor of family needs as familial stress due to the high demands placed upon principals (Ewington et al., 2008; Morford, 2002; Shoho \& Barnett, 2010). A study of new principals (Shoho \& Barnett, 2010) noted the guilt that principals experienced because job duties required them to miss important family events, and rural principals described their families as being "disappointed" by the long hours and intense requirements of the position (Ewington et al., 2008, p. 551). This tension between family needs and job expectations influenced the principal's decision to leave.

A principal's career aspirations also influence his or her departure decision. Some principals viewed less desirable positions as a stepping stone to a more desirable context (Beteille, Kalogrides, \& Loeb, 2012; Halsey \& Drummond, 2014; Shoho \& Barnett, 2010). New principals also viewed less desirable positions, often rural positions, as a necessary career entry point for first-time principals, as evidenced in statements such as "wanted my own substantive principalship - would have gone anywhere to achieve this” (Halsey \& Drummond, 2014, p. 71).

\section{Institutional Factors}

Institutional factors are those within the realm of control or influence of the school district, and they include school academic performance, principal job duties, and salary (Akiba \& Reichardt, 2004; Baker et al., 2010; Branch et al., 2013; DeAngelis \& White, 2011; Loeb et al., 2010; Morford, 2002; Papa, 2007; Pijanowski \& Brady, 2009; Preston et al., 2013; Starr \& White, 2008; Tekleselassie \& Villarreal III, 2011).

In general, low-achieving schools have been linked to higher principal turnover rates (Branch et al., 2013; DeAngelis \& White, 2011; Loeb et al., 2010). In one study (Loeb et al., 2010), the lowestachieving schools had an average principal tenure of 2.2 years while the highest-achieving schools had an average principal tenure of 3.6 years. In another study (DeAngelis \& White, 2011), schools that achieved Adequate Yearly Progress, a federal designation based upon standardized test scores, had a principal turnover rate of $20.9 \%$, while schools that did not achieve Adequate Yearly Progress had a principal turnover rate of $24.7 \%$. Schools with lower test scores had higher principal turnover.

A principal's job duties also impact principal turnover. Although the job duties of principals are extensive regardless of context, principals in a rural setting assume a multiplicity of roles due to lack of other personnel (Morford, 2002; Preston et al., 2013; Starr \& White, 2008). These duties are sometimes referred to as "hats" and include everything from Dean of Students to Director of Maintenance. One study even referred to rural principals being required to mow grass and plant flowers (Cruzeiro \& Boone, 2009).

Numerous studies (Akiba \& Reichardt, 2004; Baker et al., 2010; Papa, 2007; Pijanowski \& Brady, 2009; Tekleselassie \& Villarreal III, 2011; Tran, 2017) explore the impact of salary on principal turnover, and lower salary is generally associated with frequent turnover. For instance, the mean salary for principals who left their schools in Papa's (2007) study was $\$ 84,000$. Schools that compensated principals at a rate one standard deviation below the mean, or $\$ 68,000$, had a $76.3 \%$ likelihood of retaining their principal. Schools that compensated principals at one standard deviation above the mean, or $\$ 100,000$, had a $97.5 \%$ likelihood of retaining their principal.

\section{Environmental Factors}

Environmental factors are outside of the control of either the principal or the school district. They include community expectations, isolation, and legislative mandates.

Community expectations in a rural community can contribute to a principal's departure decision (Ewington et al., 2008; Lock, Budgen, Lunay, \& Oakley, 2012; Preston et al., 2013). Rural contexts view school leaders as community leaders, so principals are required to navigate complicated social and political relationships within the community to be successful (Preston et al., 2013). In addition, rural principals described the intense scrutiny they received from members of the public and the expectation of constant access, using phrases such as "very public property" (Lock et al., 2012, p. 70) and "being on call to the community 24 hours a day" (Lock et al., 2012, p. 70).

The professional isolation experienced by rural principals, who often have no job-alike colleague with whom to share workplace challenges and successes, is another factor that influences principals' 
departure decisions. In more than one study, rural principals expressed feelings of loneliness and vulnerability due to lack of collegial support (Graham, Paterson, \& Miller, 2008; Lock et al., 2012), and a rural principal in Morford's (2002) study summarized the isolation by saying, "In a rural community you are out there, and you are on your own!” (p. 6)

Legislative mandates about standardized testing and accountability impact all principals, but they can be especially burdensome for rural principals who do not have support structures or community buy-in regarding standardized assessment achievement (Blanton \& Harmon, 2005; Preston et al., 2013; Starr $\&$ White, 2008). Standardized compliance requirements issued at the federal or state levels require the same responses from all schools, regardless of size or location, which results in the rural principal assuming additional responsibilities to comply with mandates. In larger districts, those responsibilities can be more equitably shared among members of a larger administrative team (Preston et al., 2013).

\section{Purpose of the Study}

The purpose of this study was to investigate the factors that influenced a principal's decision to leave his or her rural school. This study sought to give rural principals in greater Minnesota a voice by allowing them to explain in their own words why they decided to leave. Minnesota proved to be a helpful research setting because it had not been explored in previous research on this topic, and the qualitative nature of this study provided an opportunity for principals to share insight that might not be ascertainable from the numerical analyses of state or national databases used in many quantitative studies.

\section{Conceptual Framework}

The conceptual framework for this study was built upon the work Greenfield (1983). Greenfield believed that the career decisions of educators were based upon the interplay of self, work, and non-work factors. Career decisions were not dependent upon isolated factors or career stage but upon how factors interacted with and compounded one another.

In this study, initial factors came from existing research and were divided into the categories of personal factors, institutional factors, and environmental factors. Factors are in Figure 1, and the arrows between factors indicate Greenfield's assertion that single factors do not influence career decisions as much as does the interplay between factors.

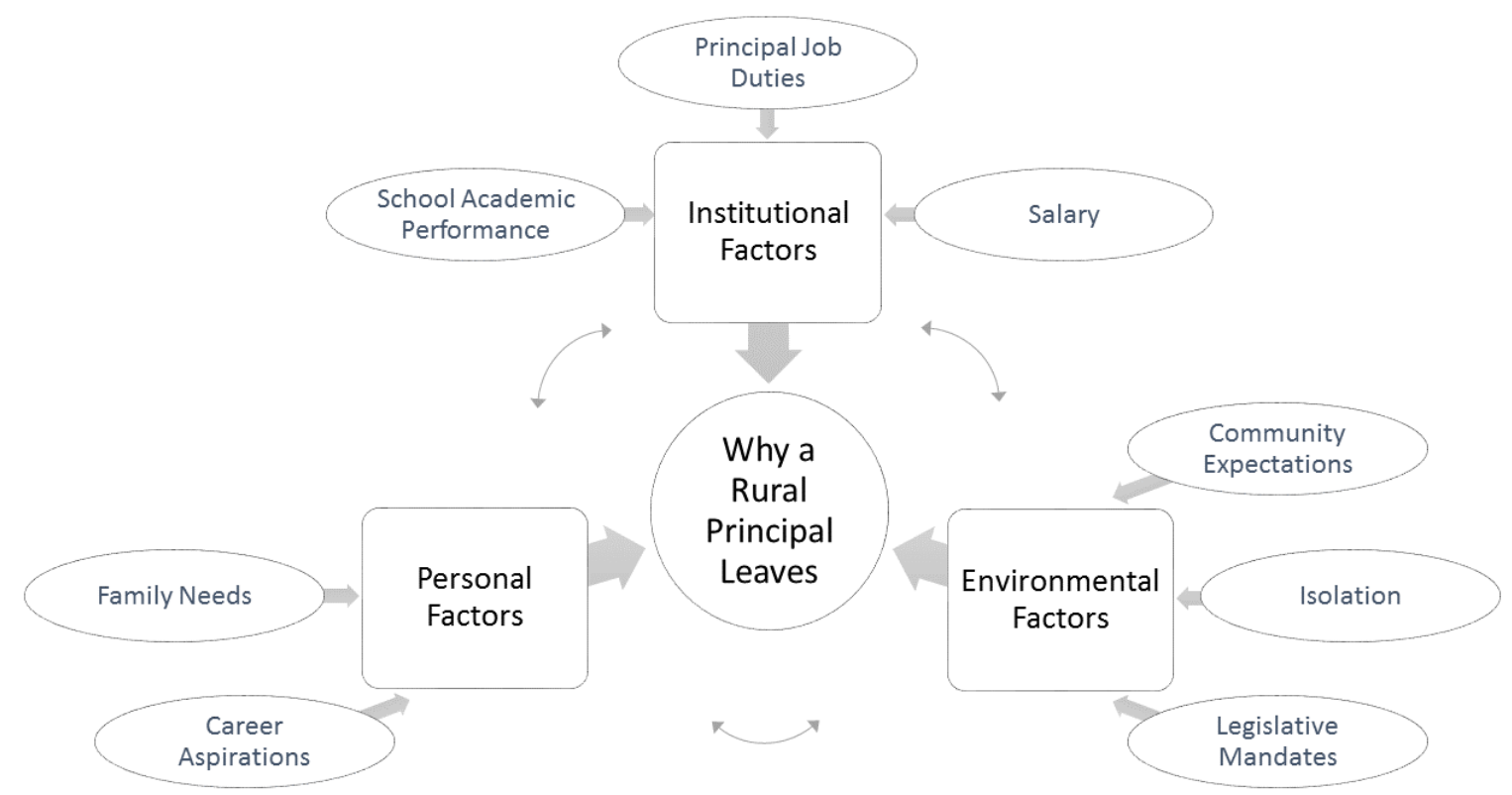

Figure 1. The initial conceptual framework for this study, based on factors in existing literature. This figure illustrates the perceived factors that influence a rural principal's departure decision. 


\section{Methodology}

This multisite case study utilized a semi-structured interview format (Merriam, 2009; Patten, 2014), which begins with a series of questions but allows for additional dialogue during the interview as needed. The categories in the conceptual framework formed the basis for the interview questions. Interview questions were revised based on multiple rounds of feedback through field tests, also called pilot tests (Patten, 2014). A team of three researchers, one of whom was an acting superintendent, provided initial feedback through three rounds of question revisions. Interview questions were then vetted through a mock interview process with two existing principals who were not respondents in the study, which resulted in a fourth round of question revisions. Questions were limited in number to allow for full discussion of each question while respecting the time commitment of respondents. The interview questions are in Table 1.

The order of questions was intentional. Interviews began with a general opening question and then proceeded through questions about each category of factors - institutional, personal, and environmental. Discussion about personal factors did not occur until the middle of the interview, after the researcher and respondent had opportunity to build rapport, because those factors might have been more sensitive or difficult to discuss. Questions in italics were added during the research process because the original questions did not provide pertinent

information. For instance, "What was your family’s perception of your work as a rural principal?” led to discussions about the nobility of the education profession. This question was changed to, "How was your family impacted by your work as a rural principal?

Respondents were selected through a stratified purposive sampling process (Orcher, 2014). A statewide elementary principals’ organization provided a list of all principals in Minnesota who left their schools within the previous year. After narrowing the list to those who left a school that had

Table 1

Interview Questions

\begin{tabular}{|c|c|c|}
\hline Research Objective & Subcategory or Theme & Question \\
\hline Opening & & - Tell me a little about why you left your previous school. \\
\hline $\begin{array}{l}\text { Explore institutional } \\
\text { factors that led to a } \\
\text { principal's departure } \\
\text { decision }\end{array}$ & $\begin{array}{l}\text { School academic } \\
\text { performance, } \\
\text { principal job duties, and } \\
\text { salary }\end{array}$ & $\begin{array}{l}\text { - How would you describe your workload at your rural } \\
\text { school? (duties, roles, hours per week) } \\
\text { - How would you describe the salary and benefits package } \\
\text { at your rural school? }\end{array}$ \\
\hline $\begin{array}{l}\text { Explore personal factors } \\
\text { that led to a principal's } \\
\text { departure decision }\end{array}$ & $\begin{array}{l}\text { Family needs and } \\
\text { career aspirations }\end{array}$ & $\begin{array}{l}\text { - What first motivated you to become a principal at a rural } \\
\text { school? Has that reality changed? If so, how? } \\
\text { - What was your family’s perception of your work as a } \\
\text { rural principal? How was your family impacted by your } \\
\text { work as a rural principal? }\end{array}$ \\
\hline $\begin{array}{l}\text { Explore environmental } \\
\text { factors that led to a } \\
\text { principal’s departure } \\
\text { decision }\end{array}$ & $\begin{array}{l}\text { Community } \\
\text { expectations, isolation, } \\
\text { and legislative mandates }\end{array}$ & $\begin{array}{l}\text { - What were the community’s expectations of you? } \\
\text { (visibility at events, involvement in civic organizations, } \\
\text { go-to person for problems of any kind) } \\
\text { - How did you connect, both personally and } \\
\text { professionally, with people outside of your rural } \\
\text { community? }\end{array}$ \\
\hline Closing & & $\begin{array}{l}\text { - If I were to give you a magic wand and you could have } \\
\text { changed anything about your rural school, what would it } \\
\text { be? What would your rural school have had to do to get } \\
\text { you to stay? } \\
\text { - Do you have anything to add that I did not ask? }\end{array}$ \\
\hline
\end{tabular}




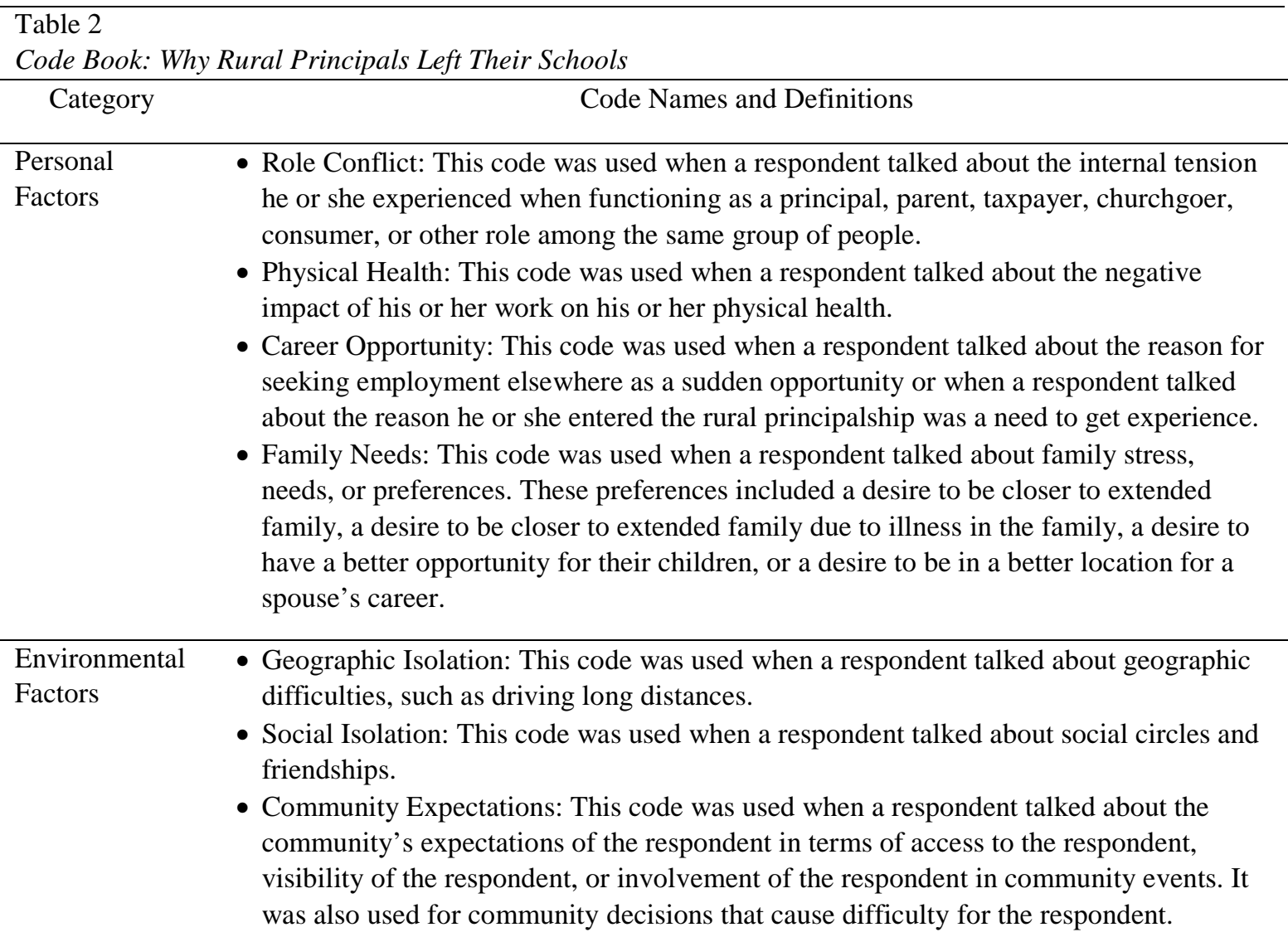

Institutional

Factors
- Workload: This code was used when a respondent talked about job duties (often referred to as "hats") and number of hours per week he or she worked.

- Lack of Professional Support: This code was used when a respondent talked about lack of support personnel (assistant principal, special education director, secretary, etc.). This code was also used when a respondent talked about principal colleagues, sometimes called job-alikes, including lack of colleagues with whom to discuss their work, frustration that colleagues did not carry their fair share of the burden, and disappointment that a colleague was looking for a job. Finally, this code was used when a respondent talked about lack of personal professional development.

- Personnel Issues: This code was used when a respondent talked about conflict with staff members and staff members not doing their jobs. It was also used when a respondent talked about the teachers' union.

- Superintendent and School Board Decisions:

o General Decisions or Relationship: This code was used when a respondent talked about relationships with or decisions made by the superintendent or school board. It also included discussions about the general functioning of the school board and discussions about the respondent feeling appreciated or unappreciated by the superintendent or school board.o Budget Cuts: This code was used when a respondent talked about district budget cuts that might have resulted in elimination of an administrative position or changes to administrative duties.

o Principal Salary and Contract Negotiations: This code was used when a respondent talked about salary, benefits, or the contract negotiations process. 
a rural census code, respondents were chosen through a random number generator according to the following geographic and gender strata: north female, north male, central female, central male, south female, south male. Geographic delineations were the regions defined by the Minnesota Association of School Administrators (2015), with Regions 1-3 in southern Minnesota, Regions 4-6 in central Minnesota, and Regions 7-8 in northern Minnesota. The total number of respondents was six. Interviews ranged from 35 to 90 minutes and took place at a location that was convenient and comfortable for respondents. Interviews were digitally recorded, transcribed by a confidential online transcription service, and edited to remove any personally identifiable information. Transcripts were analyzed for codes and themes through the following process:

1. Two initial readings to orient the researcher to the entirety of the data set.

2. At least four readings for potential statements that answered the question, "Why did this principal leave his or her rural school?" Statements were summarized with a code, and code names were drawn from existing research or the language of the respondents. This process is sometimes referred to as open coding (Merriam, 2009; Orcher, 2014). If the researcher was in doubt about the potentiality of coding a statement, the question was asked, "Is this really a reason the respondent left his or her school?” These readings produced 17 potential codes.

3. At least four additional readings per transcript to narrow the code list, clearly define each code, ensure alignment among codes, ensure alignment of codes and the research objective, and provide consistency of codes among all six transcripts. This process, sometimes called analytical coding (Merriam, 2009) or axial coding (Orcher, 2014; Patten, 2014), resulted in 13 codes. Codes were grouped into categories of personal, institutional, and environmental factors. Personal factors included role conflict, physical health, career opportunity, and family needs. Environmental factors included geographic isolation, social isolation, and community expectations. Institutional factors included workload, lack of professional support, personnel issues, and three codes relating to the superintendent and school board: general decisions or relationship, budget cuts, and principal salary and contract negotiations.

4. Final codes and definitions are in the code book in Table 2.

Transferability and credibility of data were enhanced through several methods. First, the researcher participated in a bracketing interview with an independent researcher who also reviewed the final research findings. The purpose of this interview, during which the researcher was interviewed using the same questions later used with respondents, was to alert the researcher and reviewer to potential areas of bias (Orcher, 2014). Second, the researcher maintained an audit trail in which each interaction with the data was meticulously logged (Merriam, 2009; Orcher, 2014). Third, utilizing a process that is sometimes referred to as intercoder agreement (Creswell, 2014; Orcher, 2014; Patten, 2014), an independent analyst coded all transcripts according to the definitions in the code book, with a final agreement between researcher and independent analyst of 95.6\%. Finally, member checks were conducted several times throughout the analysis process, which allowed respondents to verify or disagree with the data and findings (Creswell, 2014; Merriam, 2009; Orcher, 2014). Respondents received copies of and provided feedback about the audio recordings, written transcripts, codes assigned to their transcripts, and themes. No respondents suggested any changes at any time.

\section{Results}

A summary of the codes assigned to each interview is in Table 3. Asterisks indicate the code occurred at least one time for that respondent; the number on the right side indicates the total number of respondents for whom that code occurred.

Themes were codes that occurred for more than half of the respondents. Seven themes emerged, and they were distributed across all three categories of factors. Themes that occurred in existing literature were Career Opportunities, Family Needs, Community Expectations, Workload, and Lack of Professional Support. New themes not present in existing literature were related to the superintendent and school board. They included General Decisions or Relationship and Principal Salary and Contract Negotiations. Themes relating to superintendent and school board were so prominent that two respondents immediately responded with that theme after the 
Table 3

Codes Assigned to Respondents

\begin{tabular}{|c|c|c|c|c|c|c|c|}
\hline Code & Henry & Gayle & Sebastian & Renee & Olivia & Neil & SUM \\
\hline \multicolumn{8}{|l|}{ Personal Factors: } \\
\hline Role Conflict & * & & * & & & * & 3 \\
\hline Physical Health & & & & * & $*$ & $*$ & 3 \\
\hline Career Opportunities & $*$ & * & * & * & & $*$ & 5 \\
\hline Family Needs & $*$ & $*$ & * & * & * & * & 6 \\
\hline \multicolumn{8}{|l|}{ Environmental Factors: } \\
\hline Geographic Isolation & * & & * & & & & 2 \\
\hline Social Isolation & & & * & & & * & 2 \\
\hline Community Expectations & & * & * & * & & * & 4 \\
\hline \multicolumn{8}{|l|}{ Institutional Factors: } \\
\hline Workload & * & * & * & * & * & * & 6 \\
\hline Lack of Professional Support & $*$ & * & * & * & * & $*$ & 6 \\
\hline Personnel Issues & * & * & & & & * & 3 \\
\hline \multicolumn{8}{|l|}{ Superintendent and School Board Decisions: } \\
\hline General Decisions or Relationship & & * & $*$ & * & * & * & 5 \\
\hline Principal Salary and Contract Negotiations & * & * & & * & $*$ & $*$ & 5 \\
\hline Budget Cuts & * & & & * & & & 2 \\
\hline SUM & 9 & 8 & 9 & 9 & 6 & 11 & \\
\hline
\end{tabular}

Note. Codes were potential reasons a principal left his or her rural Minnesota elementary school. Asterisks indicate the code was assigned to at least one statement in the interview for that respondents

\section{Theme 1: Career Opportunities}

The theme of Career Opportunities occurred in five of the six interviews. Some respondents described a willingness to accept a rural principal position to acquire administrative experience. Sebastian said, "I kind of knew that to get my foot in, I was going to need to go somewhere...to get that experience.” However, that did not make his departure decision easy, even if he initially went to a rural school as a means of getting experience. Later in the interview, he said regarding his departure decision, "It was a very, very tough - it was a tougher decision than you would think.”

Other respondents did not actively seek a different position but were prompted to do so through an event or interaction. Renee described it by saying,

Then I got a phone call. Sometimes things happen in life and you just are like, "Oh." It kind of shocks you a little bit and gets you out of what you're doing, your path that you're currently on. I got a phone call from a parent in [new location] who said, "Did you know that [new location] is hiring, and I think you should apply," and I went, "Oh?"
Likewise, Henry described his career change as something he did not actively seek until encouraged to do so by a colleague:

[A colleague] one day said, "You could be happier in a different place. Have you ever thought of looking?" So once that seed got planted, then there was almost a trickle-down effect where then someone who was working in this district said, "Hey, there's an opening," and then it felt like, "Okay."

\section{Theme 2: Family Needs}

This theme emerged for all six respondents. It was not limited to a specific gender of respondent, nor was it limited to respondents of a specific age. Respondents of all life situations and circumstances indicated that family needs influenced their departure decision.

Some respondents expressed a desire to move closer to extended family. Renee explained, "My family lives in [new location]," and Neil said, "We have [number] children, grown up ... [My wife] wanted to be closer." Others wanted better circumstances for their children, as when Gayle described her new setting as more "rigorous" with greater "opportunities." Still others desired improved 
career opportunities for their spouse, which Sebastian illustrated when he said, "My wife works in [career], so getting to a community and having more opportunities that she didn't have, to go into a place like [new location] was something that was appealing to us."

Almost all respondents described the demands and stress that the rural principalship placed upon their family. Henry observed, "I'd say it was incredibly hard for [my family] to the point now where my kids ask, 'Will you keep playing with us?'” Similarly, Gayle said,

I have [children] and definitely heard from them. They acted differently in weeks where I had a lot of evening meetings and I wasn't around much. I'm able to help with homework now. I was never able to do that.

Olivia did not have young children at home at the time of her departure decision, and she also described the impact of the rural principalship on her family. She said,

So sometimes you end up being short with your family because you're stressed and tired and spread so thin in your workplace. And that's hard. And then you have to take a step back and say, "It's not their fault. It's not worth it."

\section{Theme 3: Community Expectations}

The Community Expectations theme occurred in four of the six interviews. Rural communities in Minnesota face unique challenges, and some principals experienced negative community reaction because of school consolidation discussions or failed school bond referenda. Regarding consolidation, Sebastian explained that his district had "done some athletic pairing” that led to conflicting discussions of consolidation. He said, “Okay, to be honest, as the year went on, that stuff started to build up, and the community got a little more negative towards the school.” This negativity made his work environment more challenging. Gayle said of failed school bond referenda that, "Our community was not supporting building projects," and she expressed dismay at the lack of "community support for the needs of those kids.”

Other principals experienced community pressure to be visible at athletic and other events. When discussing the expectation of attendance at evening and weekend activities, Neil said, "But you do feel that pressure, got to show up, got to get my face out there.” Renee noted receiving questions about whether she would be present at the local community festival.

This theme also included the expectation of access to the principal. When Renee was asked about community expectations, she replied, "Oh my, they wanted to have like a direct line to me. The school board members would come in and visit with me all the time.” Expectation of access was noticeably different in her new, non-rural position. She explained the difference by saying,

They [my previous community] wanted to see me a lot, which is very different now where I'm at where I don't see school board members a whole lot, and I don't have people coming in and expecting me to be at basketball games.

\section{Theme 4: Workload}

All respondents described challenges related to a heavy workload. When Henry was asked about workload, he described it by saying, "It was on me all the time, so it was in our life, enmeshed in everything, and constant, constant, constant, constant.” Similarly, Neil said, "You can work as hard as you want....You can never go home.”

When asked about roles performed as a rural principal, Renee said, "Just say I was everything." Olivia concurred when she noted, "You name it, you end up doing it." Some of the roles described by respondents were Curriculum Director, District Assessment Coordinator, Title I and II Coordinator, Preschool Director, Special Education Director, Staff Development Director, Human Resources Manager, Support Staff Supervisor, Transportation Director, Technology Director, Counselor, Athletic or Activities Director, Dean of Students, School Improvement Coordinator, Instructional Coach, Response to Intervention Coordinator, Professional Learning Community Leader, and Teacher Evaluator.

Workload was frustrating for respondents not simply because of the load but because it impacted their ability to perform at their job to the level they desired. Sebastian explained, "When you have all these roles, you kind of focus on just managing." Olivia noted a similar frustration when she said, So basically everything is a mile wide and an inch deep. So you feel like you're a jack of all trades and master of nothing. As a person who wants to do well I was constantly pushing myself to be innovative, be on the cutting edge, work with everybody on those things. 


\section{Theme 5: Lack of Professional Support}

This theme was closely linked to Workload and also occurred across all six transcripts. When asked about professional support, some respondents expressed a desire for additional office personnel, like an assistant principal or a full-time secretary. For instance, when asked what she would have changed about her rural school, Olivia said, "Probably to have an assistant principal.” Similarly, regarding office personnel, Gayle said of her new position, "I have now learned what it feels like to have a true, have your own secretary."

Others noted professional support personnel available in their new positions that were not available in their rural school. Renee explained,

The amount of stress in work that I had to do in [previous location], not having supports was very challenging. Now where I'm at, they have so many people. I was looking at the staff when I was looking at [new location] in their website and I was like, "Oh my gosh, they have innovation teams. They have techy people. Oh my gosh, they have content specialists.” That really made it easier to make that transition. Also included in this theme were relationships with principal colleagues. Some respondents had no other principal colleagues with whom to share the burden of leadership. Most respondents had only one principal colleague. When the colleague relationship was negative, sometimes due to differences of opinion about contract negotiations or leadership style, the work environment became uncomfortable. When the colleague relationship was positive, the respondent often considered leaving, in part, because the colleague was also considering a departure. Gayle, who experienced positive collegial relationships, said, "The superintendent had been looking for a couple of years, but knowing that my high school colleague was also looking made it hard to think about what [the school district] could be like."

\section{Theme 6: Superintendent and School Board: General Decisions or Relationship}

Special note should be taken of the final two themes, as they both relate to the superintendent or school board. Themes relating to the superintendent or school board were not present in existing literature about principal turnover, but they emerged in some form across all respondents in this study.
In two interviews, this theme was the first response provided by principals when asked a general question about why they left their school. For instance, Gayle began her interview by saying, "I left my previous school because of primarily the school board dynamics and the dysfunction within that group that really made it more difficult for me to do my work well.” She described power struggles and micromanagement "that made it difficult to carry out those strong initiatives that we needed to for our kids.” Olivia, too, described the micromanagement of the school board, including the overriding of administrative decisions about discipline, scheduling, or athletics.

Other respondents described a lack of support. Neil, when discussing a difficult personnel decision, said, "I didn't feel the superintendent stood behind me strong enough either...He didn't want to ruffle any feathers." Olivia, when describing the pressure of raising test scores, said she was "feeling no support from the superintendent. And having to lead the charge on that, lead the direction on that, along with everything else that you're doing. And then not being appreciated for that.”

The lack of appreciation alluded to by Olivia was a common thread across several interviews. Neil, when asked what would have kept him in his rural school, said, "Being appreciated for the amount of work you do.”

\section{Theme 7: Superintendent and School Board: Principal Salary and Contract Negotiations}

In their rural school districts, respondents often participated in contract negotiations directly with the superintendent or school board. Henry, when explaining the many layers that factored into his departure decision, said, "There was also not being in a bargaining unit, and negotiations were quite challenging to negotiate with your boss and have your boss be the go-between." Olivia echoed his sentiments when she expressed, "And I think one of the most difficult things in a small school district like that is you're negotiating all by yourself. You don't have a group of people to negotiate with and to talk about things." She further described the difficulty by saying, "And being in a room with three board members all by yourself is not easy. They like to push you around, and you don't have a team to support you."

Respondents described the frustrations of low salary, particularly when combined with heavy 
workload. Olivia said, “And you still have all the work of a principal in any other district, plus more, because of all the different hats you're wearing, but you're not compensated for it. So that was difficult.” Likewise, Gayle compared workload and salary when she explained, "When I started looking at my output and the value of that output, [salary] did make a difference [in my decision to leave].”

Olivia, when asked for one thing her district would have had to do to get her to stay, said, "Well, I think they would have needed to provide me with a fair salary." Similarly, Neil said, "Yeah, it would have been salary. Otherwise, I loved it.”

\section{Conclusion}

Principal turnover impacts student achievement (Branch et al., 2013; Brockmeier et al., 2013; Mascall \& Leithwood, 2010; Miller, 2013). Because of the high turnover rate for principals (NCES, 2013) and the challenges of recruitment and retention of principals in rural settings (Howley \& Pendarvis, 2002; Pijanowski et al., 2009), rural school districts would benefit from understanding the factors that lead to a principal's departure. Without an understanding of why principals leave, rural school districts cannot intentionally create systems that encourage effective principals to stay.

There is hope for rural school districts. The majority of themes that arose during this study were classified as Institutional Factors, or those within the realm of control of the school district, which indicates that rural school districts have the ability to alter their practices or systems to reduce principal turnover.

The majority of themes that arose during this study were present in existing literature. Some of those themes, particularly workload and lack of professional support, were so strong as to have emerged for all six respondents. Although rural school districts face budget constraints that prevent the hiring of extensive support personnel, they can creatively seek opportunities to support their principals. Some of those options do not necessarily cost money. For instance, two respondents specifically mentioned the need for a secretary with technological skills, because the principal ended up doing secretarial work. Other respondents described a more equal sharing of duties among existing administrators.

Two themes, both related to the school board and superintendent, were not present in existing literature, and those themes merit additional discussion. Their absence in existing literature could be for at least two reasons. First, unlike the majority of principal turnover studies in the United States, this study was qualitative in design. It was not limited to pre-defined variables in state or national databases, which do not measure the principal's perception of his or her relationship with the school board and superintendent. Second, this study focused on the rural context. Rural principals, because of the size of their school district, often have more frequent and direct interactions with the school board and superintendent than do principals in larger districts.

The rural principal's relationship with the school board and superintendent is crucial. Respondents expressed frustration due to micromanagement, lack of clear direction, and lack of appreciation. Other areas of frustration were salary and the contract negotiation process. Although larger salaries would have been helpful for respondents, the frustration was not simply about money. Their treatment by the school board or superintendent during the negotiation process was described in ways that were frustrating and painful.

Again, the good news for rural school districts is that these factors are within their control. Rural school boards and superintendents can take a leadership role in expressing appreciation for the tireless work that rural principals perform, whether through fair and transparent conversations at the negotiating table or through casual conversations with community members at the local coffee shop table. In addition, the rural principals in this study desired to have strong leadership with a clear vision, and they desired the superintendent and school board to allow principals to carry out that vision without micromanaging daily decisions about athletics and discipline. Such micromanagement cost precious time and resources, which were already in short supply because of the high demands of a rural setting.

As with all research, this study had limitations, particularly scope and sample, that should be considered when determining applicability to other contexts. While this study added a small number of voices to the collective conversation about principal turnover, many more voices are needed. A larger qualitative research team could access greater numbers of respondents from other geographic contexts, time periods, and school levels. For instance, urban high school principals might have very different experiences, which could result in additional insights about principal turnover. 
Furthermore, as a complement to the research about why principals leave, future research could explore factors that prompt a principal to stay. Finally, future research could explore the cause-and-effect relationship of several factors, as it is unclear which comes first-for instance, do low test scores cause principals to leave, or does turnover cause low test scores?

In addition to sample and scope limitations, this study was limited by the possibility of self-reporting bias. The researcher attempted to mitigate this limitation by explaining the extreme care taken to protect confidentiality and prevent inadvertent identifiers through the deletion of personally identifiable information from transcripts, the limited inclusion of respondent demographic information, the use of pseudonyms, and the destruction of audio files at the conclusion of the study. Respondents seemed comfortable during the interview process, sometimes even sharing potentially embarrassing information about their own mistakes during their work as a rural principal, which indicated their willingness to provide fair and honest assessments of their experiences.

The rural principalship is complex and challenging, but it is also a position of tremendous possibility. With attention to the themes described in this study, rural school districts and communities can take positive steps toward the creation of systems that will promote principal stability which, in turn, will promote success for their most important asset-their children.

\section{References}

Akiba, M., \& Reichardt, R. (2004). What predicts the mobility of elementary school leaders? An analysis of longitudinal data in Colorado. Education Policy Analysis Archives, 12(18).

Baker, B. D., Punswick, E., \& Belt, C. (2010). School leadership stability, principal moves, and departures: Evidence from Missouri. Educational Administration Quarterly, 46(4), 523-557. doi:10.1177/0013161X10383832

Battle, D. (2010). Principal attrition and mobility: Results from the 2008-09 principal follow-up survey. First look. (No. 2010-337). Washington, DC: National Center for Education Statistics.

Beteille, T., Kalogrides, D., \& Loeb, S. (2012). Stepping stones: Principal career paths and school outcomes. Social Science Research 41, 904-919. http://dx.doi.org/10.1016/j.ssresearch.2012.03.00 3

Blanton, R. E., \& Harmon, H. L. (2005). Building capacity for continuous improvement of math and science education in rural schools. The Rural Educator, 26(2), 6-11.

Branch, G. F., Hanushek, E. A., \& Rivkin, S. G. (2013). School leaders matter. Education Next, 13(1), 62-69.

Brockmeier, L. L., Starr, G., Green, R., Pate, J. L., \& Leech, D. W. (2013). Principal and school-level effects on elementary school student achievement. International Journal of
Educational Leadership Preparation, 8(1), 4961.

Creswell, J. W. (2014). Research design: Qualitative, quantitative, and mixed methods approaches (4th ed.). Thousand Oaks, CA: Sage Publications.

Cruzeiro, P. A., \& Boone, M. (2009). Rural and small school principal candidates: Perspectives of hiring superintendents. The Rural Educator, 31(1), 1-9.

DeAngelis, K. J., \& White, B. R. (2011). Principal turnover in Illinois public schools, 2001-2008. (No. 2011-2). Southern Illinois University: Illinois Education Research Council.

Ewington, J., Mulford, B., Kendall, D., Edmunds, B., Kendall, L., \& Silins, H. (2008). Successful school principalship in small schools. Journal of Educational Administration, 46(5), 545-561. doi:10.1108/09578230810895483

Farley-Ripple, E., Solano, P. L., \& McDuffie, M. J. (2012). Conceptual and methodological issues in research on school administrator career behavior. Educational Researcher, 41(6), 220-229.

Gates, S. M., Ringel, J. S., Santibanez, L., Guarino, C., Ghosh-Dastidar, B., \& Brown, A. (2006). Mobility and turnover among school principals. Economics of Education Review, 25(3), 289-302. doi:10.1016/j.econedurev.2005.01.008

Graham, L., Paterson, D., \& Miller, J. (2008). Leadership in Australian rural schools: Bush track, fast track. New York, NY: Annual 
Meeting of the American Educational Research Association.

Greenfield, W. D., Jr. (1983). Career dynamics of educators: Research and policy issues. Educational Administration Quarterly, 19(2), 526.

Hacker, H. K. (2015, July 28). A principal concern: 1 in 3 Dallas ISD schools will have new leaders in fall. The Dallas Morning News. Retrieved from http://www.dallasnews.com/news/education/hea dlines/20150725-a-principal-concern-1-in-3dallas-isd-schools-will-have-new-leaders-infall.ece

Halsey, R. J., \& Drummond, A. (2014). Reasons and motivations of school leaders who apply for rural, regional and remote locations in Australia. Australian and International Journal of Rural Education, 24(1), 69-77.

Illinois State Board of Education. (2016). eReport card public site. Retrieved from http://webprod.isbe.net/ereportcard/publicsite/get searchcriteria.aspx

Kraegel, L. (2016, January 27). Nome public schools considers new program to fight principal turnover. KNOM Radio Mission. Retrieved from http://www.knom.org/wp/blog/2016/01/27/nome -public-schools-considers-new-program-to-fightprincipal-turnover/

Lock, G., Budgen, F., Lunay, R., \& Oakley, G. (2012). The loneliness of the long-distance principal: Tales from remote western Australia. Australian and International Journal of Rural Education, 22(2), 65-77.

Loeb, S., Kalogrides, D., \& Horng, E. L. (2010). Principal preferences and the uneven distribution of principals across schools. Educational Evaluation and Policy Analysis, 32(2), 205-229. doi:10.3102/0162373710369833

Mascall, B., \& Leithwood, K. (2010). Investing in leadership: The district's role in managing principal turnover. Leadership and Policy in Schools, 9(4), 367-383.

Merriam, S. B. (2009). Qualitative research: A guide to design and implementation. San Francisco, CA: Jossey-Bass.

Miller, A. (2013). Principal turnover and student achievement. Economics of Education Review, 36, 60-72. doi:10.1016/j.econedurev.2013.05.004

Morford, L. M. (2002). Learning the ropes or being hung: Organizational socialization influences on new rural high school principals. (No.
ED464783). Eastern Illinois University: Annual Meeting of the American Educational Research Association.

National Center for Education Statistics. (2013). Schools and staffing survey [Data file]. Retrieved from https://nces.ed.gov/surveys/sass/tables_list.asp

Orcher, L. T. (2014). Conducting research: Social and behavioral science methods (2nd ed.). Glendale, CA: Pyrczak Publishing.

Papa, F., Jr. (2007). Why do principals change schools? A multivariate analysis of principal retention. Leadership and Policy in Schools, 6(3), 267-290. doi:10.1080/15700760701263725

Patten, M. L. (2014). Understanding research methods: An overview of the essentials (9th ed.). Glendale, CA: Pyrczak Publishing.

Partlow, M. C., \& Ridenour, C. S. (2008). Frequency of principal turnover in Ohio's elementary schools. Mid-Western Educational Researcher, 21(2), 15-16.

Pijanowski, J. C., \& Brady, K. P. (2009). The influence of salary in attracting and retaining school leaders. Education and Urban Society, 42(1), 25-41. doi:10.1177/0192636509343963

Pijanowski, J. C., Hewitt, P. M., \& Brady, K. P. (2009). Superintendents' perceptions of the principal shortage. NASSP Bulletin, 93(2), 85-95. doi:10.1177/0192636509343963

Preston, J. P., Jakubiec, B. A. E., \& Kooymans, R. (2013). Common challenges faced by rural principals: A review of the literature. The Rural Educator, 35(1).

Shoho, A. R., \& Barnett, B. G. (2010). The realities of new principals: Challenges, joys, and sorrows. Journal of School Leadership, 20(5), 561-596.

Starr, K., \& White, S. (2008). The small rural school principalship: Key challenges and cross-school responses. Journal of Research in Rural Education, 23(5), 1-12.

Sun, M., \& Ni, Y. (2016). Work environments and labor markets: Explaining principal turnover gap between charter schools and traditional public schools. Educational Administration Quarterly, 52(1), 144-183.

Tekleselassie, A. A., \& Villarreal III, P. (2011). Career mobility and departure intentions among school principals in the United States: Incentives and disincentives. Leadership and Policy in Schools, 10(3), 251-293. doi:10.1080/15700763.2011.585536 
The Chicago Public Education Fund. (2015).

Chicago's fight to keep top principals: 2015 school leadership report. Retrieved from http://thefundchicago.org/bestcitytolead/

Tran, H. (2017). The impact of pay satisfaction and school achievement on high school principals' turnover intentions. Educational Management
Administration \& Leadership, 45(4), 621-638. doi:10.1177/1741143216636115

Tuoti, G., \& Sanna, J. (2016, April 11). Many factors contribute to principal turnover. The Arlington Advocate. Retrieved from

http://arlington.wickedlocal.com/article/2012016 $\underline{\text { 0/NEWS/16041978 }}$

\section{About the Author:}

Cindy Hansen is principal at Pine Island Elementary in Pine Island, MN and a doctoral student at Bethel University in St. Paul MN. Contact Cindy at chansenteach@gmail.com 